\title{
Chemical synthesis and steady state characterization of a nanocrystalline lithium cobalt oxide
}

\author{
Y. Neira-Guio ${ }^{1, *}$, L.C. Canaria-Camargo ${ }^{2}$, J.A. Gómez-Cuaspud ${ }^{3}$, E. Vera-López ${ }^{3}$
}

\author{
Edited by \\ Juan Carlos Salcedo-Reyes \\ (salcedo.juan@javeriana.edu.co) \\ 1. Grupo desarrollo y aplicaciones \\ de nuevos materiales (DANUM). \\ Universidad Pedagógica y \\ Tecnológica de Colombia, \\ Av. Central del Norte 39-115. \\ Tunja, Colombia. \\ 2. Grupo de Investigación en Álgebra \\ y Análisis. Universidad Pedagógica y \\ Tecnológica de Colombia, \\ Av. Central del Norte 39-115. \\ Tunja, Colombia. \\ 3. Instituto para la Investigación e \\ Innovación en Ciencia y Tecnología \\ de Materiales. INCITEMA. \\ Universidad Pedagógica y \\ Tecnológica de Colombia, \\ Av. Central del Norte 39-115. \\ Tunja, Colombia. \\ *ariatna.neira@uptc.edu.co \\ Received: 13-05-2019 \\ Accepted: $17-04-2020$ \\ Published on line: 13-06-2020 \\ Citation: Neira-Guio, \\ Canaria-Camargo, Gómez-Cuaspud, \\ Vera-López. Chemical synthesis and \\ steady state characterization of a \\ nanocrystalline lithium cobalt oxide, \\ Universitas Scientiarum, 25 (2): 203-225, 2020 \\ doi: $10.11144 /$ Javeriana.SC25-2.csas
}

\begin{abstract}
Lithium cobalt oxide $\left(\mathrm{LiCoO}_{2}\right)$ is one of the most relevant components in lithium-ion batteries. The array of sought-after features of $\mathrm{LiCoO}_{2}$ depends on its synthesis method. In this work we synthesized and characterized a nanocrystalline $\mathrm{LiCoO}_{2}$ oxide obtained with a wet chemistry synthesis method. The oxide obtained was a homogeneous powder in the nanometric range $(5-8 \mathrm{~nm})$ and exhibited a series of improved properties. Characterization by FTIR and UV-Vis techniques led to identifying citrate species as main products in the first step of the synthesis process. X-ray diffraction (XRD), Raman, and transmission electron microscopy (TEM) characterizations led to identifying a pure crystalline phase of the synthesized $\mathrm{LiCoO}_{2}$ oxide. Steady state electrical characterization and solid-state impedance spectroscopy determined the high conductance of the synthesized oxide. All these features are desirable in the design of cathodes for lithium ion batteries.
\end{abstract}

Keywords: Nanomaterial; Li-Ion Batteries; nanocrystalline; steady-state.

\section{Introduction}

Lithium cobalt oxide $\left(\mathrm{LiCoO}_{2}\right)$ is a structural material with a laminar configuration that efficiently stores energy. Because of its structural stability and long life in the processes of load cycling, $\mathrm{LiCoO}_{2}$ is used in the design of positive electrodes in lithium ion (Li-ion) batteries [1-3] and electronics, including modern mobile devices [4]. 
Funding:

Institute for Research and Innovation in Materials Science and Technology (INCITEMA) and the Universidad Pedagógica y Tecnológica de ColombiaTunja (UPTC)

Electronic supplementary material: N.A.

OPEN $\bigcirc$ ACCESS
Achieving cost-effective $\mathrm{LiCoO}_{2}$ production while improving its energy density, life-cycle, and safety, is a current research goal. Understanding the processes that bring about $\mathrm{LiCoO}_{2}$ structural features, such as particle size, geometric shape, surface properties, and crystalline phase, is key to manipulating and improving this material [5-6].

Several works on $\mathrm{LiCoO}_{2}$ obtention confirm that adequate nanometric structures provide an effective pathway to promote $\mathrm{Li}^{+}$ions and generate a high charge capacity, even at high discharging rates [7-10]. $\mathrm{LiCoO}_{2}$ cathodes synthesized from metal oxides exhibit temperature associated evaporation of lithium species. Consequently, adjustments in the process of $\mathrm{LiCoO}_{2}$ chemical synthesis could improve its effectiveness. These improvements involve changes in the material's microstructure, as in previous works in which it has been possible to insert active materials in glassy matrices [11-14].

Steady-state electrical characterization of compact pellets of $\mathrm{LiCoO}_{2}$ facilitates the analysis of alternating current in simple circuits and the solving of DC circuits. Furthermore, the ability of the system to return to its steady after electrical disturbance can be analyzed in these materials [14].

Improved $\mathrm{LiCoO}_{2}$ synthesis methods involve the use of mixed oxides, spinels, olivines, and polyanionic oxides, among others [15, 16]. Further adaptation of $\mathrm{LiCoO}_{2}$ synthesis methods include hydrothermal synthesis [17], sol-gel [18], combustion [19], precipitation [20], and spray pyrolysis [21]. Cathode materials synthesized with these methods exhibit improved anisotropic features, such as crystalline phase, purity, size, and optimal particle distribution $[22,23]$.

In this work we synthesized and evaluated the properties of $\mathrm{LiCoO}_{2}$. Our synthesis method is based on a chemical route of combustion, starting from corresponding metallic nitrates. Our aim is to develop materials with morphological, superficial, and structural properties ideal in the design of advanced cathode components in lithium-ion batteries.

\section{Materials and Methods}

The synthesis of lithium cobalt oxide $\mathrm{LiCoO}_{2}$ required $\mathrm{LiNO}_{3}$ anhydrous and $\mathrm{Co}\left(\mathrm{NO}_{3}\right)_{2} .6 \mathrm{H}_{2} \mathrm{O}$, both from Merck (99.99\%). Each reactant was dissolved in deionized water $(18 \mathrm{M} \Omega \mathrm{cm})$ to a concentration of $1.0 \mathrm{Mol} \mathrm{L}^{-1}$. Subsequently, a citric acid solution $\left(1.0 \mathrm{Mol} \mathrm{L}^{-1}\right)$ was added in a $0.5: 1.0$ molar ratio, in relation to the total content of metalions, following Gómez and Valencia [24-25]. 
The system remained in reflux for 2 hours, under a nitrogen atmosphere of $50 \mathrm{mmHg}$ at $80^{\circ} \mathrm{C}$, and magnetic stirring $(500 \mathrm{rpm})$. The obtained dissolution formed a solid gel, which was subsequently treated on a hot plate at $120{ }^{\circ} \mathrm{C}$ to obtain a solid porous foam. The solid precursor of $\mathrm{LiCoO}_{2}$ was collected, grounded in agate mortar, and sieved through a 400 US standard mesh for the FTIR analysis in a PerkinElmer Paragon 1000 FTIR equipment and Raman spectroscopic characterization. This characterization was made in a Raman spectrometer HR-UV 800 infinity microprobe with a CCD detector $\left(-70{ }^{\circ} \mathrm{C}\right)$, and a laser power of $10.7 \mathrm{~mW}$ equipment.

The solid precursor solid of $\mathrm{LiCoO}_{2}$ were calcined at $850^{\circ} \mathrm{C}$ for 2 hours in a tubular furnace under nitrogen flow $\left(50 \mathrm{~mL} \cdot \mathrm{min}^{-1}\right)$, ensuring the consolidation of the crystalline phase. The characterization of the calcined material was performed by X-ray diffraction (XRD) in a PANAlytical X'per PRO MPD diffractometer, using an ultra-fast X'Celerator detector in a Bragg Brentano arrangement, using the $\mathrm{CuK} \alpha$ radiation $(\mathrm{K} \alpha=0.154186 \mathrm{~nm})$. The diffractogram pattern was evaluated between 10 and $90^{\circ} 2 \theta_{3}$ with steps of 0.02 , and the results obtained were analyzed with the X'Pert High Score Software. The crystal size of $\mathrm{LiCoO}_{2}$ sample was calculated using the Equation 1, as follows:

$$
D=\frac{k * \lambda}{\beta * \cos \theta}
$$

Where $\mathrm{D}$ is the average crystallite size in $\mathrm{nm}, \lambda(\sim 0.154056 \mathrm{~nm})$ is the wavelength of $\mathrm{X}$-ray radiation, $\theta$ is the Bragg angle and $\beta$ is the full width at half of the maximum (FWHM) signal.

The detailed structural aspects of the $\mathrm{LiCoO}_{2}$ oxide were analyzed with transmission electron microscopy (TEM). A JEOL 2100 microscope-equipped with a $\mathrm{LaB}_{6}$ thermionic cannon, an acceleration voltage of $200 \mathrm{kV}$, and a CCD camera-was employed for this purpose.

The textural characteristics of the $\mathrm{LiCoO}_{2}$ were established via $\mathrm{N}_{2}$ adsorption isotherms at $77 \mathrm{~K}$ in a conventional volumetric equipment, Autosorb 3B, Quantachrome. Further UV characterization was performed in a Mapada 1000 equipment at a wavelength range of $190 \mathrm{~nm}-1100 \mathrm{~nm}$, to obtain the corresponding band-gap.

Electrical property measurements of $\mathrm{LiCoO}_{2}$ were performed on an Autolab potentiostat-galvanostat equipment, at room temperature between $10 \mathrm{mHz}$ 
and $1 \mathrm{MHz}$, using a copper electrode and a system for pressure coupling. Measurements were performed ten times, in complete frequency cycles, from which an average result was obtained. Bode curves were also obtained from these measurements. To corroborate the values of electrical conductance $(G)$ from resistance values $(\mathrm{Z})$ the Eq. (2) was employed as follows:

$$
G=\frac{1}{Z}
$$

\section{Results and Discussion}

\section{FTIR spectroscopic features}

The characterization by infrared spectroscopy (FTIR) of the solid precursor of $\mathrm{LiCoO}_{2}$, shown in Fig. 1, allowed to determine the formation of citrate species. This is a fundamental aspect for the obtention of ceramic oxides under the studied reaction conditions. We identified absorption bands of carboxyl groups attached to the COO-M bond, located at $1409 \mathrm{~cm}^{-1}$. We observed a citrate-type precursor-related deformation signal, which is consistent with carboxyl terminal groups (-COO-) associated with the used citric acid as

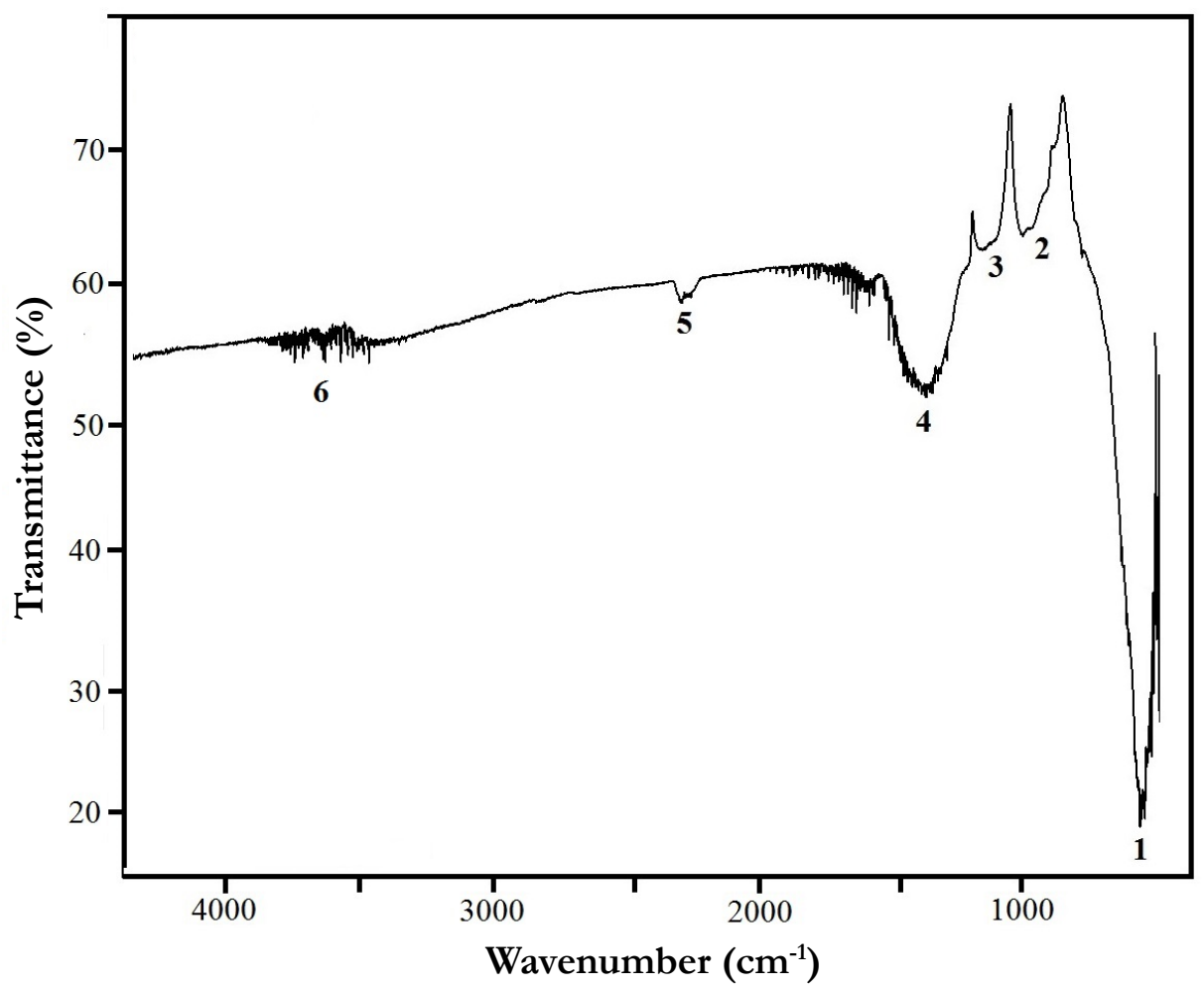

Figure 1. FTIR spectrum of the citrate precursor of $\mathrm{LiCoO}_{2}$ with its main absorption bands. 
chelate agent. Previous results confirm that the acid $\mathrm{pH}$ of the medium favors the obtention of this type of chemical species of importance for the purity of the final oxide $[24,25]$.

We observed a band located at $2345 \mathrm{~cm}^{-1}$ associated with the vibration mode of the $\mathrm{O}=\mathrm{C}=\mathrm{O}$ bond. The occurrence of this band was attributed to the presence of $\mathrm{CO}_{2}$ in the structure of the material due to the combustion process in the synthesis method. The tension band related to $\mathrm{C}=\mathrm{O}$ and $\mathrm{C}-\mathrm{H}$ bonds was observed at $1048 \mathrm{~cm}^{-1}$ and $1055 \mathrm{~cm}^{-1}$. This band is associated with the presence of alcohol and ketonic groups, as well as to the type of vibration tension of the $\mathrm{C}-\mathrm{H}$ bond, which is present in the precursor. The bands observed around $1600 \mathrm{~cm}^{-1}-1750 \mathrm{~cm}^{-1}$, correspond to carbonyl groups and can be related to the formation of ketones, by a process related with the decomposition of citric acid and associated to $\mathrm{C}=\mathrm{O}$ and $\mathrm{O}-\mathrm{C}=\mathrm{O}$ groups [26, 27].

The band observed at $584 \mathrm{~cm}^{-1}-554 \mathrm{~cm}^{-1}$ is related with a vibration bending (m) of the $\mathrm{MO}$ bond, which corresponds to an oxygen bond and a $\mathrm{Co}^{3+}$ cation. Their vibrational modes $\mathrm{U}(\mathrm{OMO})$ are a function of $\mathrm{pH}$, favoring the formation of metal-ligand bonds. Based on previous information and data reported by Gómez and Valencia [24], we can relate the presence of citrate-species in our synthesis process to the main functional groups indicated in Table 1.

\section{X-ray diffraction characterization}

The relationship between the indexed and the experimental XRD patterns of $\mathrm{LiCoO}_{2}$ oxide after combustion is shown in Fig. 2. The analysis via the X'Pert High-Score software classified our $\mathrm{LiCoO}_{2}$ material with ICSD code: 00-016-0427, and placed it in the rhombohedral geometry of spatial group $R-3 m$ (166).

Based on the most intense signals from the diffraction pattern along facets

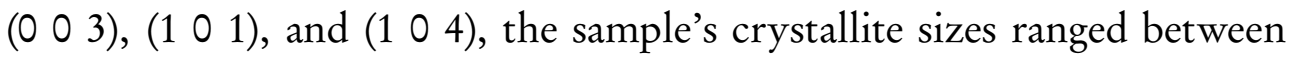
$5 \mathrm{~nm}-8 \mathrm{~nm}$. This agrees well with the results of Chinarro et al. [28], in which citrate precursors provide a way to obtain homogeneous and nanometric materials. The combustion reaction led to a strong a brief heat release that was absorbed by the synthesized oxides. The gases from the combustion dissipated, conforming a material with large surface area and manometric crystal size. These are relevant features of the obtained oxide, consequence of the employed synthesis method $[29,30]$. 
Table 1. Main infrared absorption bands.

\begin{tabular}{cccc} 
Band & Wavenumber $\left(\mathbf{c m}^{-1}\right)$ & Bond & Vibration mode \\
\hline 1 & $554-584$ & M-O & Bending $(m)$ \\
\hline 2 & 822 & M-O & Bending $(m)$ \\
\hline 4 & $1048-1055$ & C-O, C-H & Bending $(m)$ \\
\hline 5 & 1409 & COO-M & Deformation \\
\hline 6 & 2345 & O $=\mathrm{C}=\mathrm{O}$ & Bending $(m)$ \\
\hline
\end{tabular}

The XRD signals located between $20^{\circ}-35^{\circ}$, indicate the presence of a pyrite-marcasite family oxide of $\mathrm{LiO}_{2}$, with space group Pnnm (58) and JCPDS No. 04-003-4382. This is a likely $\mathrm{LiNO}_{3}$ decomposition by-product, resulting during the combustion process. The calcination temperature of $850{ }^{\circ} \mathrm{C}$, increases $\mathrm{LiCoO}_{2}$ crystallinity, but it is insufficient to eliminate $\mathrm{LiO}_{2}$

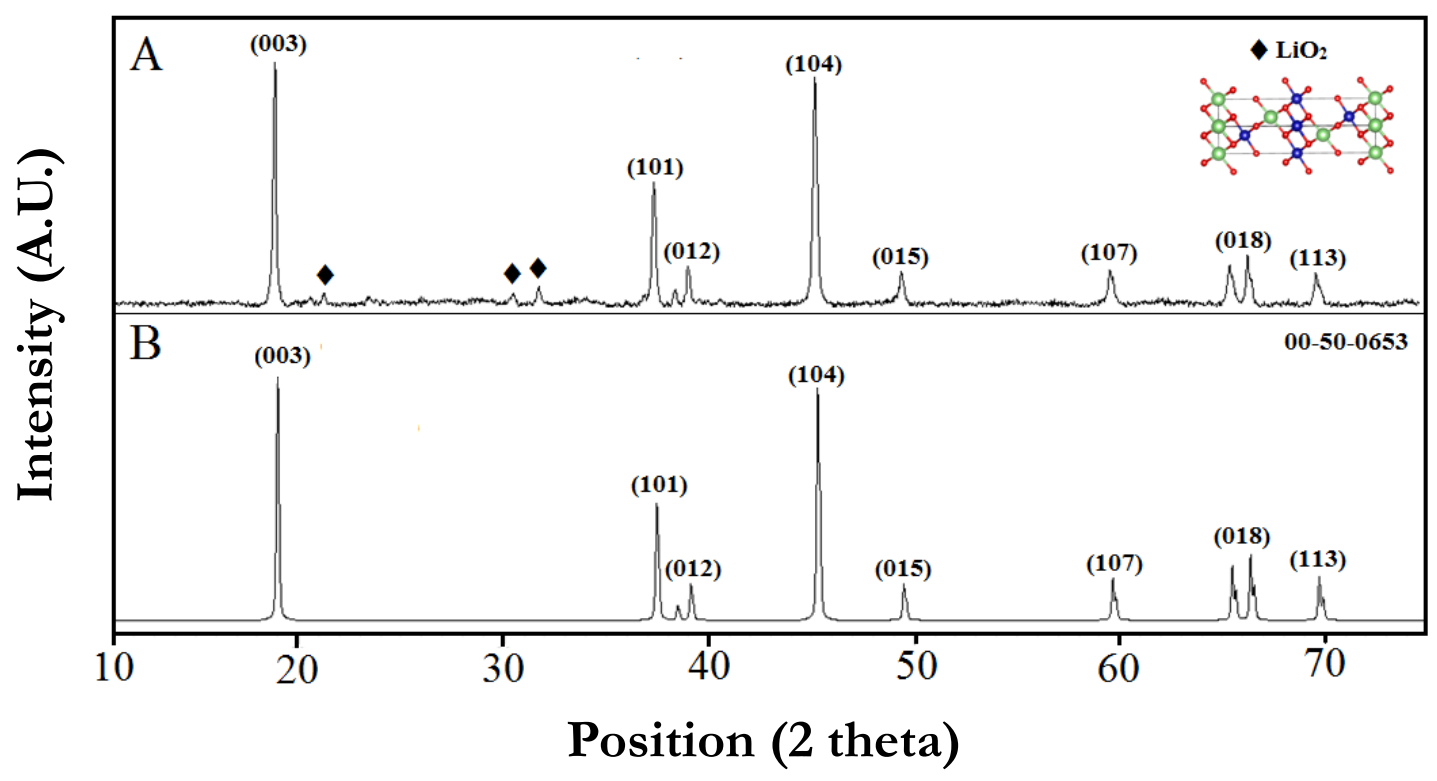

Figure 2. X-ray diffraction patterns of the calcined $\mathrm{LiCoO}_{2}$ : indexed pattern (A) and simulated pattern (B), as obtained by Rietveld refinement. 


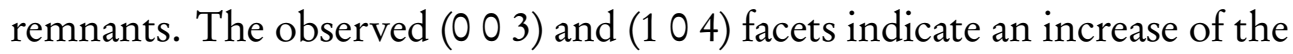
$\mathrm{LiCoO}_{2}$ phase. Furthermore, the presence of pyrite-marcasite oxide, derived from the synthesis procedure, has been observed for many $\mathrm{LiCoO}_{2}$-based materials [31, 32].

Simulation of the $\mathrm{LiCoO}_{2}$ system unit cell, resulted in the estimation of the main cell parameters: $a=2.8166, b=2.8166, c=14.045$, with $\alpha=$ $\beta=90^{\circ}$ and $\gamma=120^{\circ}$. This set of estimated parameters corroborates an oxide structure with the geometry shown in Fig. 3: the $\mathrm{O}^{2-}$ ions are located along the $\left(\begin{array}{lll}0 & 0 & 3\end{array}\right)$ facet, and $\mathrm{Li}^{+}$and $\mathrm{Co}^{3+}$ ions are placed in the octahedral sites of the alternate layers. This geometry is related with low consolidation temperatures during the synthesis process in accordance with Cabrera and Levi $[33,34]$.

\section{Raman characterization}

Raman characterization of the synthesized $\mathrm{LiCoO}_{2}$ (Fig. 4) revealed two active vibration modes, $A_{1 g}$ and $E_{g}$, located in the region of $400 \mathrm{~cm}^{-1}$ to $700 \mathrm{~cm}^{-1}$. These are due to the vibrations of the oxygen atoms present in the oxide structure [35]. The $\mathrm{A}_{1 \mathrm{~g}}$ mode corresponded to the higher frequency Raman band resulting from the vibration of two oxygen atoms. The $\mathrm{E}_{g}$ mode (double degeneration $d z, d x-y$ ) was revealed by a frequency band at $486 \mathrm{~cm}^{-1}$. In this $\mathrm{E}_{g}$ mode, lithium atoms, together with cobalt cations, vibrate parallel-but in opposite direction-to oxygen atoms [36].

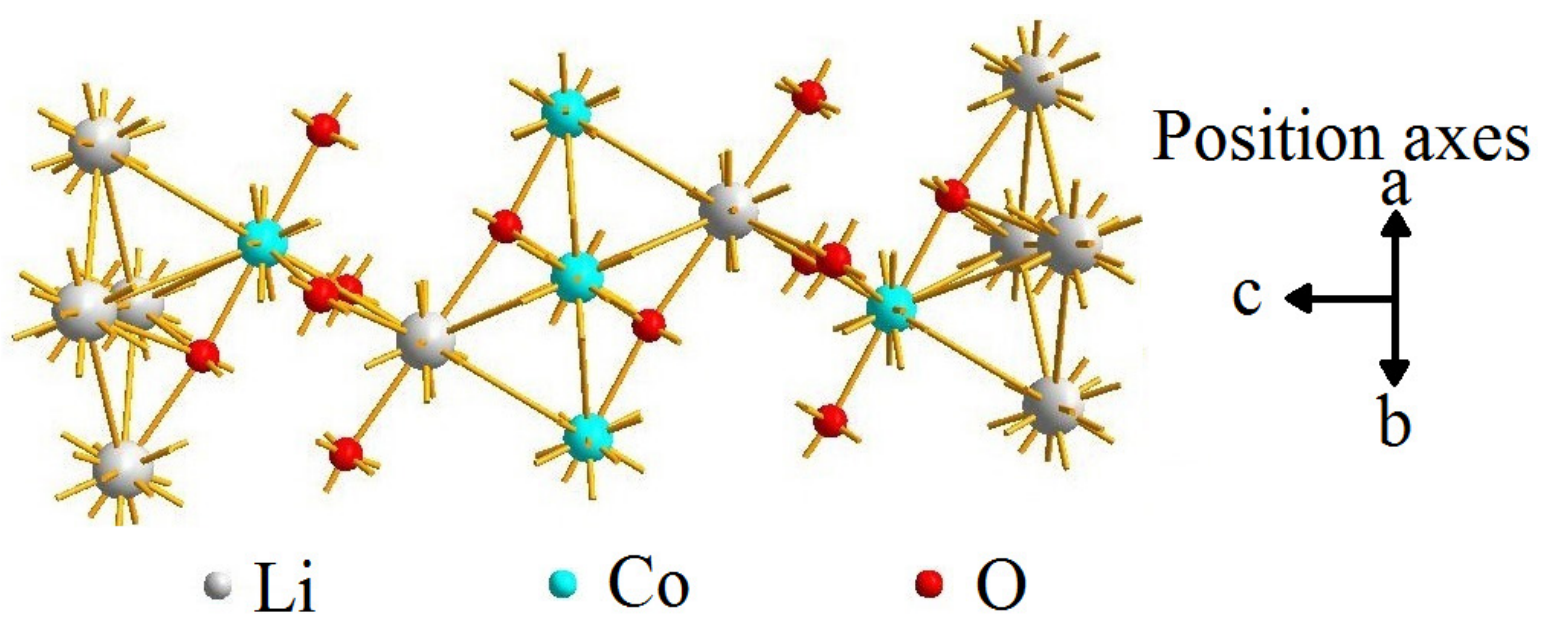

Figure 3. Simulated unit cell for the obtained oxide using the ELMIX software. 


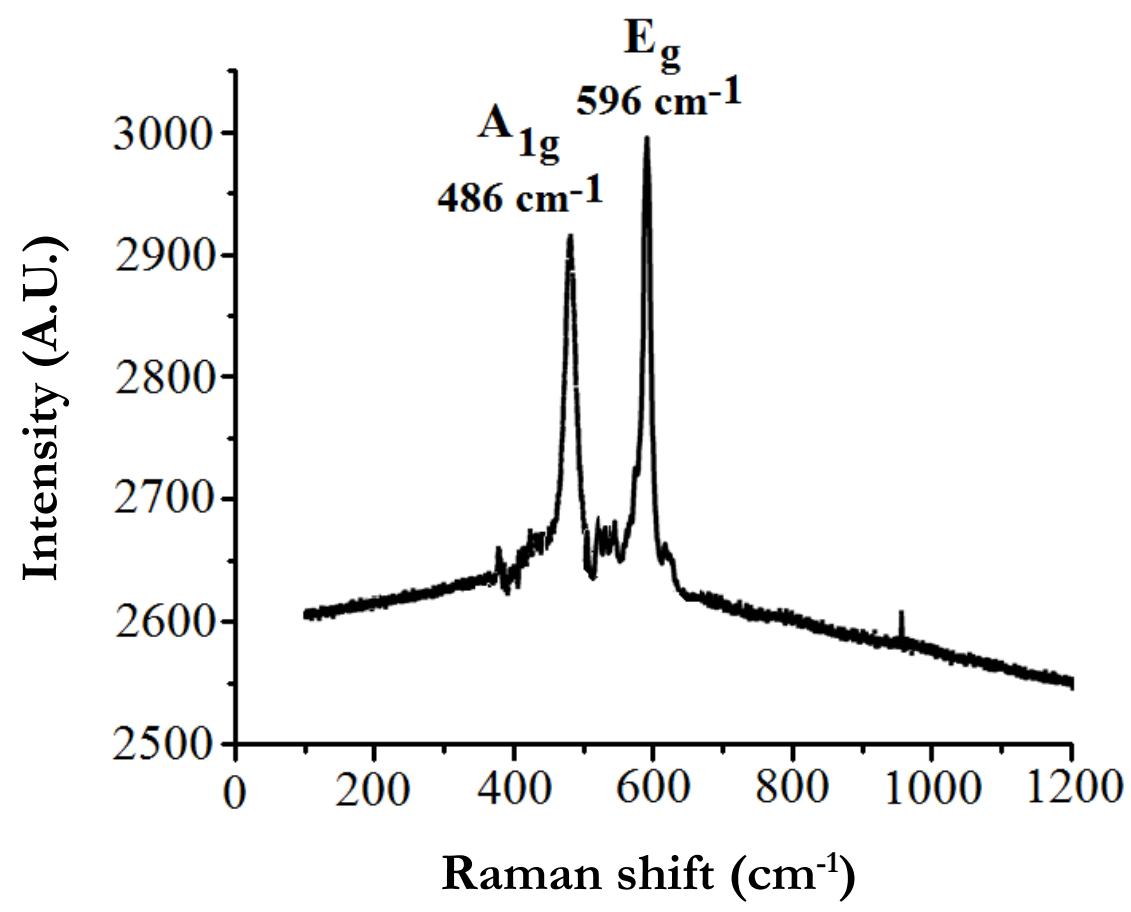

Figure 4. Raman spectrum for the synthesized oxide with its main vibrational signals.

The signals that dominate the Raman spectrum were observed at $486 \mathrm{~cm}^{-1}$ and $596 \mathrm{~cm}^{-1}$. These correspond to the vibrational flexion modes attributed to the $\mathrm{A}_{1 g}$ and $\mathrm{E}_{g}$ vibrational modes, associated with the presence of $\mathrm{LiCoO}_{2}$ $[8,37,38]$.

According to Santiago et al. [13], these Raman results are consistent with a structure, devoid of spinels or secondary phases, resulting from a calcination process. The calcination temperature of $850^{\circ} \mathrm{C}$ promoted the final evolution of the precursor to a pure oxide form. The qualitative analysis of the main signals is consistent with previous works in which the $\mathrm{LiCoO}_{2}$ was obtained in a single phase and exhibited bands attributed to oxygen vibrations involving mainly Co-O stretching $\left(\mathrm{A}_{1 g}\right)$ and $\mathrm{O}-\mathrm{Co}-\mathrm{O}$ bending $\left(\mathrm{E}_{g}\right)$ vibrations $[39$, 40]. The spectrum lacks the so-called defect band (D band), related to C-C stretching modes related with graphite or carbonaceous species [41].

The active bands observed in the range of $500 \mathrm{~cm}^{-1}-580 \mathrm{~cm}^{-1}$, with the presence of vibration modes for the metal-oxygen bonds, corresponds to a lithium deficiency, as previously reported by Julien and Escobar [42, 43], According to the irreducible representations derived from the molecular symmetry, the $\mathrm{E}_{g}-\mathrm{A}_{1 g}$ signals are sites of octahedral configuration and corroborate the obtained results of X-ray diffraction. 


\section{Transmission electron microscopy}

TEM micrographs of a population of $150 \mathrm{LiCoO}_{2}$ particles revealed nanometric crystallite sizes with a Gaussian distribution and a median size of $6.2 \mathrm{~nm}-7.2 \mathrm{~nm}$ (Fig. 5). The observed size range is in accordance with that estimated for $\mathrm{LiCoO}_{2}$ particles under XRD measurements.

TEM-derived data showed that our synthesized $\mathrm{LiCoO}_{2}$ crystals grew towards the preferential $\left(\begin{array}{ll}1 & 0\end{array}\right)$ and $(003)$ facets, revealing a highly crystalline structure with interplanar $d$ distances of 0.04 microns (Fig. 6A-6F). The general view of images between $0.2 \mu \mathrm{m}$ and $0.5 \mu \mathrm{m}$ confirms a homogeneous distribution of oxide particles (Fig. 6B-6E). This agrees with Okubo et al. results $[44,45]$, in which the electron diffraction patterns revealed the characteristic geometry of an oxide structure along atomic layers.

Additionally, the absorption isotherms of the material entailed a surface area of $115 \mathrm{~m}^{2} \mathrm{~g}^{-1}$, corroborating that solids of small sizes feature large contact areas. This is crucial in the development of electrolyte materials for Li-ion batteries. Material large contact areas improve carriers' interchange charge capacity [46].

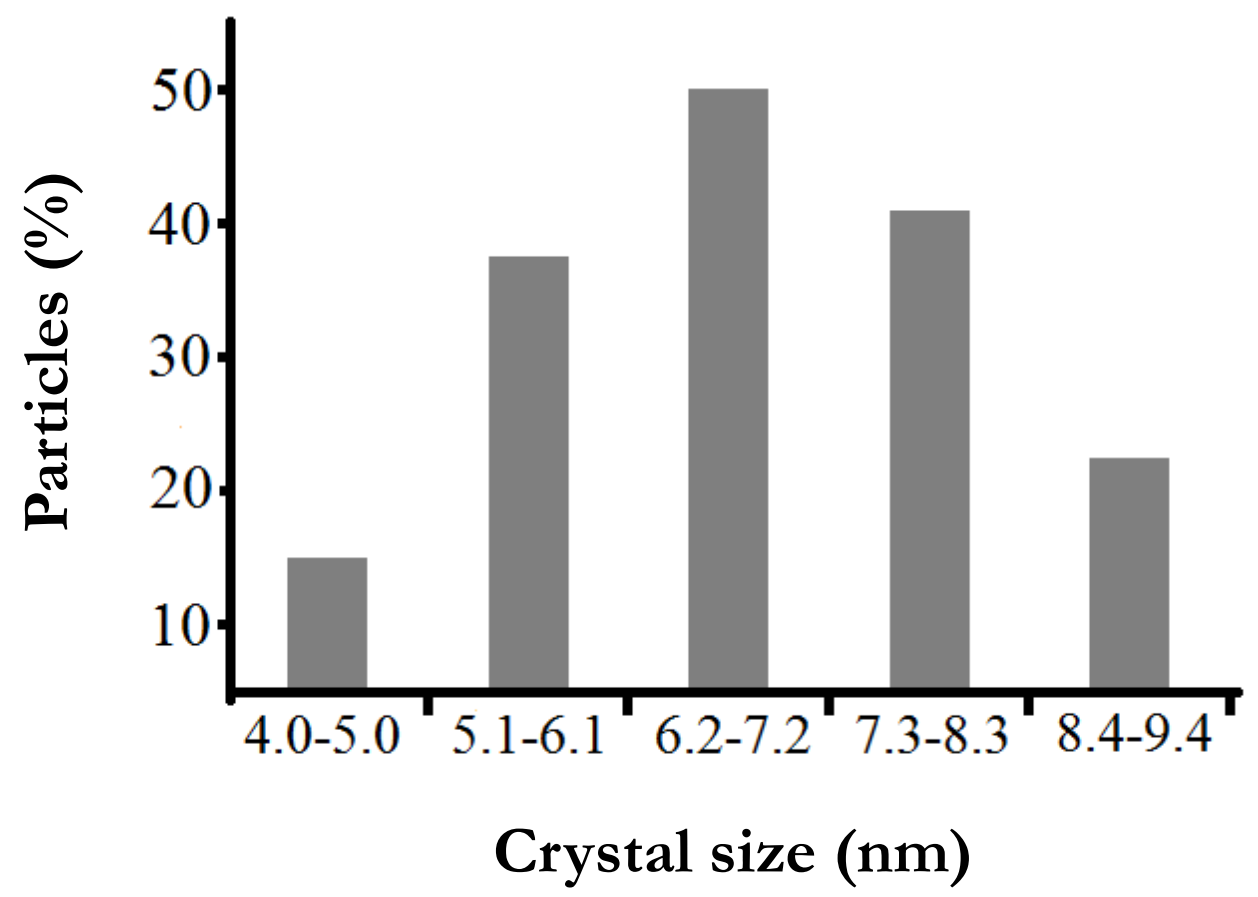

Figure 5. $\mathrm{LiCoO}_{2}$ Crystallite size distribution, from 150 Transmission electron micrographs. 

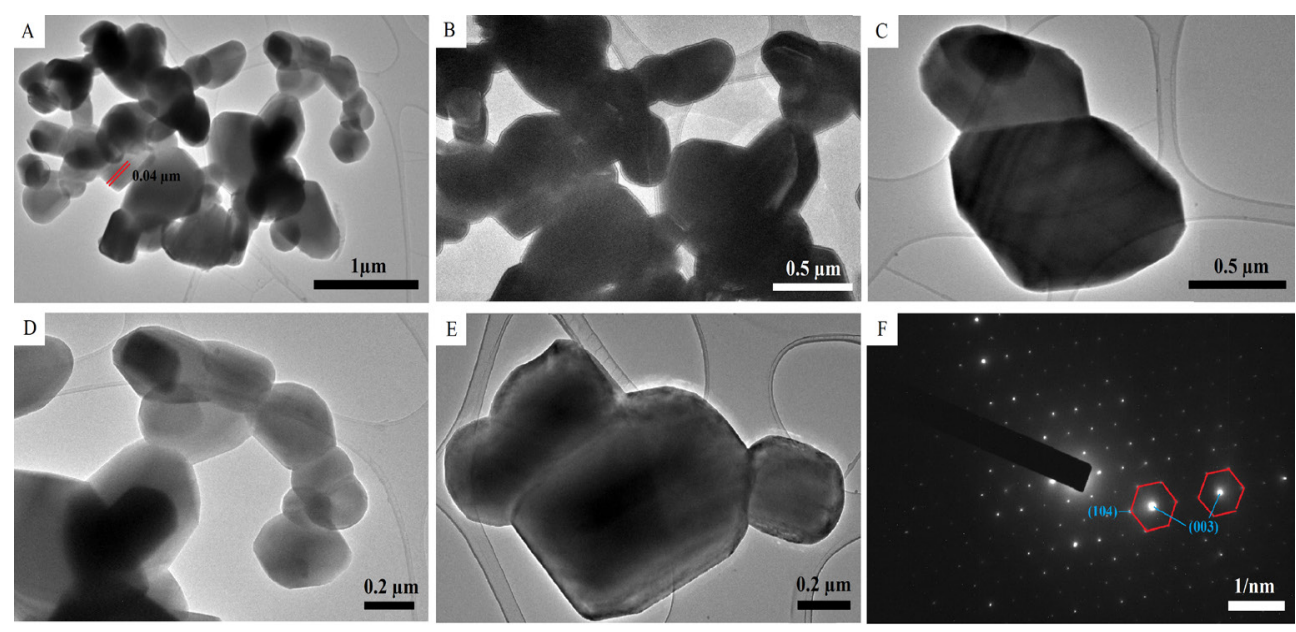

Figure 6. Transmission electron micrographs of the synthesized $\mathrm{LiCoO}_{2}$ system and one electron diffraction image. (A) At $1 \mu \mathrm{m}$ with interplanar $d$ distances of 0.04 microns; (B) General view at $0.5 \mu \mathrm{m}$; (C) Magnification at $0.5 \mu \mathrm{m}$; (D) Magnification at $0.2 \mu \mathrm{m}$; (E) Magnification at $0.2 \mu \mathrm{m}$; and (F) electron diffraction images at $1 \mathrm{~nm}$ with main diffraction signals at facets $\left(\begin{array}{llll}1 & 0 & 4\end{array}\right)$ and $\left(\begin{array}{llll}0 & 0 & 3\end{array}\right)$.

\section{$\mathrm{UV}-\mathrm{Vis}$ spectroscopy}

We subjected the oxide to ultraviolet visible UV-Vis spectroscopic characterization and determined the oxide's features at an electronic transition frequency of $9.96 \times 10^{-11} \mathrm{~Hz}$. The signal depicted in Fig. 7, is consistent with a $\mathrm{n} \rightarrow \pi *$ transition that confirms the presence of an unsaturated group in the molecule providing $p$ electrons. This, in turn, agrees with a previous observation that the active cation in the absorption process is located in the B position of the oxide [47].

The UV-Vis study also allowed measuring the transmittance levels of the $\mathrm{LiCoO}_{2}$ oxide. The transmittance value observed was of $62 \%$. This value is at least $3 \%$ lower than the theoretical value from similar materials [48]. This finding highlights the possibility of designing transparent Li-ion cells.

\section{$\mathrm{LiCoO}_{2}$ sample electrical properties}

Steady state electrochemical evaluation of the $\mathrm{LiCoO}_{2}$ sample revealed a logarithmic trend of negative slope (Fig. 8). This indicates resistance in the equivalent circuit (horizontal plateau before $100 \mathrm{~Hz}$ ). The slope after $100 \mathrm{~Hz}$ is associated with the behavior of a capacitor system, indicating a faster charge transfer in the $\mathrm{LiCoO}_{2}$ sample. 


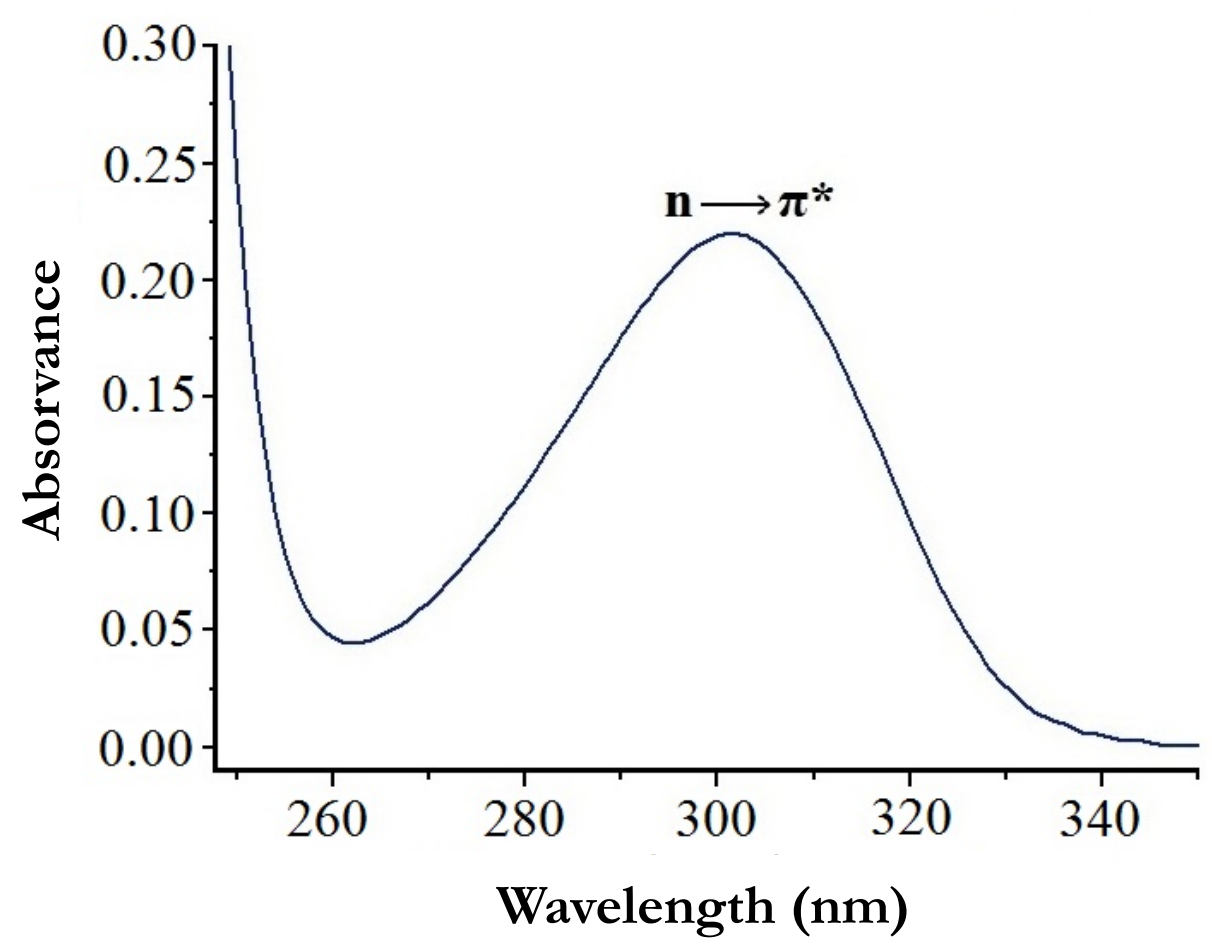

Figure 7. Ultraviolet absorption spectrum of the studied $\mathrm{LiCoO}_{2}$ oxide.

Our observations are consistent with the arrangement of the atoms in the $\mathrm{LiCoO}_{2}$ structure and its mode of ion transport. Regarding the latter, the double-layer capacitance in parallel promotes the accumulation of ions near the electrode surface and induces the attraction of opposite sign charges, thus forming a double electrical layer. This behavior has been observed in type $p$ semiconductor materials during the process of electric transport $[49,50]$.

The Bode diagram depicted in Fig. 8 represents the cutoff frequency of $\mathrm{LiCoO}_{2}$ oxide. The process occurs in the active sites of insertion and disintegration of lithium ions in the laminar structure of the oxide. Such process, depends mainly on the atomic disposition of $\mathrm{Li}$ ions and the defects of the material [51].

The frequency values are expressed by means of an equivalent circuit. An equivalent circuit consists of an interface of different electrical elements in which the resistance alternates with a frequency of $5.00 \mathrm{~Hz}$ passes through the material. In Fig. 8, $\mathrm{R}_{\text {sol }}$ stands for the resistance of the medium, $\mathrm{C}$ the double layer capacitance, and $\mathrm{R}$ the resistance to load transfer with a value of $140 \Omega$. This resistance value is caused by the load transport reactions in the borders and inside the grains of the material [52]. 


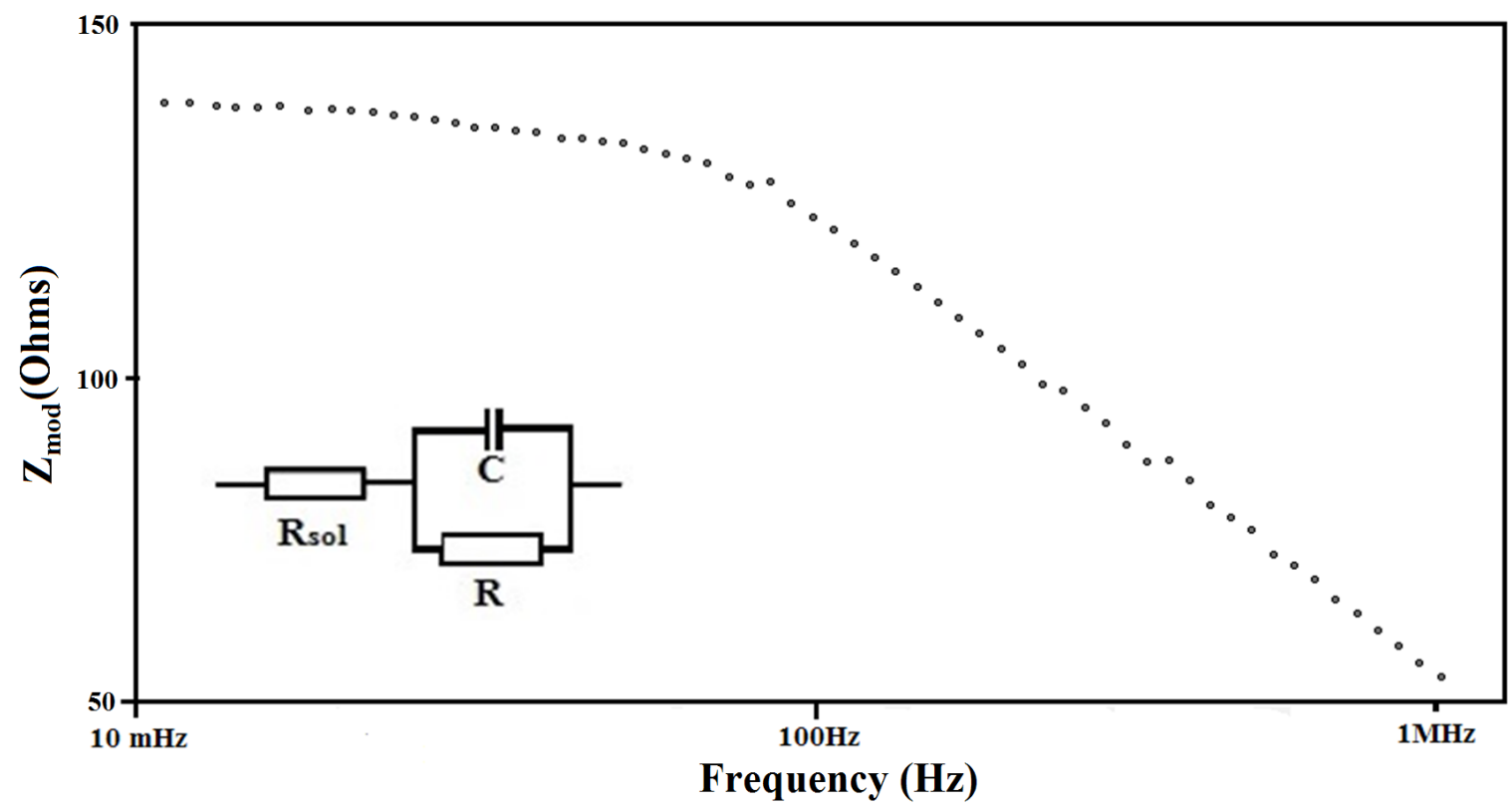

Figure 8. Ultraviolet absorption spectrum of the studied $\mathrm{LiCoO}_{2}$ oxide.

The electrical conductance $(G)$, obtained from resistance values $(Z)$ of $159.3 \Omega$ was $G=6.27 \times 10^{-3} \Omega^{-1} \mathrm{~cm}^{-1}$. Such a value, is consistent with a conductance process that occurs at the grain boundaries. Furthermore, the observed low temperature and the concentration of electronic holes inside the grain has been previously reported [53].

\section{Conclusions}

The employed $\mathrm{LiCoO}_{2}$ synthesis method favors the conformation of intermediate citrate species. They correspond with characteristic compounds derived from initial synthesis process between nitrates and citric acid. These are crucial to the consolidation of crystalline pure $\mathrm{LiCoO}_{2}$.

Our $\mathrm{LiCoO}_{2}$ characterization results showed that it is possible to design materials with a high degree of purity, crystallinity, and homogeneity. The compound we synthesized and characterized has a nanometric crystalline structure and a high surface area. This makes it a desirable component of Li-ion battery electrodes.

Finally, the enhanced conductance of our $\mathrm{LiCoO}_{2}$ solid is its most prominent feature. This is due to the formation of conducting interfacial regions that facilitate the passage of electric current along nanoscopic grains. Furthermore, this feature confirms the effectiveness of our proposed synthesis method. 


\section{Acknowledgments}

The authors thank the financial support of the Institute for Research and Innovation in Materials Science and Technology (INCITEMA) and the Universidad Pedagógica y Tecnológica de Colombia- Tunja (UPTC), where this research was carried out.

\section{Conflict of Interests}

The authors declare having no conflict of interests.

\section{References}

[1] Zaghib K, Mauger A, Groult H, Goodenough J, Julien C. Advanced electrodes for high power Li-ion batteries. Materials, 6: 1028-1049.2013.

doi: $10.3390 / \mathrm{ma} 6031028$

[2] Zhao J, Wang L, El X, Wan C, Jiang C. J. Kinetic Investigation of $\mathrm{LiCoO}_{2}$ by Electrochemical Impedance Spectroscopy (EIS). International Journal of Electrochemical Science, 5: 478-488, 2010. http://www.electrochemsci.org/papers/vol5/5040478.pdf

[3] Hu G, Cao J, Peng Z, Cao Y, Du K. Enhanced high-voltage properties of $\mathrm{LiCoO}_{2}$ coated with $\mathrm{Li}\left[\mathrm{Li}_{0.2} \mathrm{Mn}_{0.6} \mathrm{Ni}_{0.2}\right] \mathrm{O}_{2}$. Electrochimica Acta, 149: 49-55, 2014.

doi: 10.1016/j.electacta.2014.10.072

[4] Villca J, Vargas M, Yapu W, Blanco M, Benavente F, Cabrera S. New Pyrolytic/Atrano Route for $\mathrm{LiCoO}_{2}$ y $\mathrm{LiMn}_{2} \mathrm{O}_{4}$ Cathodic Electrodes Syntheses. Revista Boliviana De Quimica, 31: 82-85, 2014.

http://www.scielo.org.bo/pdf/rbq/v31n2/v31n2_a07.pdf

[5] Jeong S, Park S, Cho J. High-Performance, Layered, 3D-LiCoO Cathodes with a Nanoscale Co3O4 Coating via Chemical Etching. Advanced Energy Materials, 1: 68-372, 2011.

doi: 10.1002/aenm.201100029 
[6] Shuai H, Chunhui W, Ling Z, Xifeng Z, Li S, Jun Z, Chunxian Z, Chenghuan H, Xiaoming X, Lishan L. Hydrothermal-assisted synthesis of surface aluminum-doped $\mathrm{LiCoO}_{2}$ nanobricks for high-rate lithium-ion batteries. Ceramics International, 44: 14995$15000,2018$.

doi: 10.1016/j.ceramint.2018.05.128

[7] Yang WD, Hsieh CY, Chuang HJ, Chen YS. Preparation and characterization of nanometric-sized $\mathrm{LiCoO}_{2}$ cathode materials for lithium batteries by a novel sol-gel method. Ceramics International, 36 (1): 135-140, 2010.

doi: 10.1016/j.ceramint.2009.07.011

[8] Bezza I, Luais E, Ghamouss F, Zaghrioui M, Tran-van F, Sakai $\mathrm{J}$. $\mathrm{LiCoO}_{2}$ with double porous structure obtained by electrospray deposition and its evaluation as an electrode for lithium-ion batteries. Journal of Alloys and Compounds, 805: 19-25, 2019.

doi: 10.1016/j.jallcom.2019.07.062

[9] Abdul-Aziz NA, Abdullah TK, Mohamad AA. Synthesis of $\mathrm{LiCoO}_{2}$ Prepared by Sol-gel Method. Procedia Chemistry, 19: 861 864, 2016.

doi: 10.1016/j.proche.2016.03.114

[10] Chao D, Wang L, Shen W, Guo S. Effects of the lateral sizes and basal plane structure of graphene on the electrochemical properties of $\mathrm{LiCoO}_{2}$. Journal of Alloys and Compounds, 785: 557$562,2019$.

doi: 10.1016/j.jallcom.2019.01.126

[11] Rodrigues S, Munichandraiah N, Shukla A. Novel solutioncombustion synthesis of $\mathrm{LiCoO}_{2}$ and its characterization as cathode material for lithium-ion cells. Journal of Power Sources, 102(1-2): 322-325, 2001.

doi: 10.1016/S0378-7753(01)00770-4

[12] Kalyani P, Kalaiselvi V, Muniyandi N. A new solution combustion route to synthesize $\mathrm{LiCoO}_{2}$ and $\mathrm{LiMn}_{2} \mathrm{O}_{4}$. Journal of Power Sources, 111 (2): 232-238, 2002.

doi: 10.1016/S0378-7753(02)00307-5

[13] Santiago EI, Andrade AVC, Paiva-Santos CO, Bulhões L. Structural and electrochemical properties of $\mathrm{LiCoO}_{2}$ prepared by combustion synthesis. Solid State Ionics, 158: 91-102, 2003.

doi: 10.1016/S0167-2738(02)00765-8 
[14] PietrzakTK, Wasiucionek M, Michalski'TK, Kaleta A, Garbarczyk JE. Highly conductive cathode materials for Li-ion batteries prepared by thermal nanocrystallization of selected oxide glasses. Materials Science and Engineering B, 213: 140-147, 2016.

doi: 10.1016/j.mseb.2016.05.008

[15] Xin H, Jun W, Haiping J, Kloepsch R. Ionic liquid-assisted solvothermal synthesis of hollow $\mathrm{Mn}_{2} \mathrm{O}_{3}$ anode and $\mathrm{LiMn}_{2} \mathrm{O}_{4}$ cathode materials for Li-ion batteries. Journal of Power Sources, 293: 306-311, 2015.

doi: 10.1016/j.jpowsour.2015.04.106

[16] Zuo D, Tian G, Li X, Chen D, Shu K. Recent progress in surface coating of cathode materials for lithium ion secondary batteries. Journal of Alloys and Compounds, 706: 24-40, 2017.

doi: 10.1016/j.jallcom.2017.02.230

[17] H Ji, G Yang, X Miao, A Hong. Efficient microwave hydrothermal synthesis of nanocrystalline orthorhombic $\mathrm{LiMnO}_{2}$ cathodes for lithium batteries. Electrochimica Acta, 55: 3392, 2010.

doi: 10.1016/j.electacta.2010.01.010

[18] Kwon T, Ohnishi T, Mitsuishi K, Ozawa T, Takada K. Synthesis of $\mathrm{LiCoO}_{2}$ epitaxial thin films using a sol-gel method. Journal of Power Sources, 274: 417-423, 2015.

doi: 10.1016/j.jpowsour.2014.10.070

[19] Fumo D, Jurado J, Segadães A, Frade J. Combustion synthesis of iron-substituted strontium titanate perovskites, Materials Research Bulletin, 32: 1459-1470, 1997.

doi: 10.1016/S0025-5408(97)00117-7

[20] Gómez-Cuaspud J, Schmal. M. Nanostructured metal oxides obtained by means polymerization-combustion at low temperatura for $\mathrm{CO}$ selective oxidation. International Journal of Hydrogen Energy, 38: 7458-7468, 2013.

doi: 10.1016/j.ijhydene.2013.04.024

[21] Palacio L. Métodos de síntesis de nuevos materiales basados en metales de transición. Revista Facultad de Ingeniería, 32: 51-61, 2004.

https://www.redalyc.org/pdf/430/43003205.pdf 
[22] Cai Y, Huangn Y, Wang X, Jian D, Tang X. Long cycle life, high rate capability of truncated octahedral $\mathrm{LiMn}_{2} \mathrm{O}_{4}$ cathode materials synthesized by a solid-state combustion reaction for lithium ion batteries. Ceramics International, 40: 14039-14043, 2014.

doi: 10.1016/j.ceramint.2014.05.130

[23] Xu F, Yan H, Chen J, He M, Zhang Z, Fan C, Liu G. Improving electrochemical properties of $\mathrm{LiCoO}_{2}$ by enhancing thermal decomposition of Cobalt and Lithium carbonates to synthesize ultrafine powders. Ceramics International, 43: 6494-6501, 2017.

doi: 10.1016/j.ceramint.2017.02.071

[24] Gómez-Cuaspud J, Valencia-Ríos J. Síntesis De Óxidos Tipo Perovskita, Mediante Polimerización Con Ácido Cítrico Y Combustión Con Glicina. Revista Colombiana de Quimica, 38: 289302, 2009.

https://revistas.unal.edu.co/index.php/rcolquim/article/view/13467

[25] Cruz F, Gómez-Cuaspud JA. Synthesis of praseodymium doped cerium oxides by the polymerization-combustion method for application as anodic component in SOFC devices. Journal of Physics: Conference Series, 687, 2016.

doi: 10.1088/1742-6596/687/1/012046

[26] Marcilla A, Gómez M, Beltrán D, Berenguer IB. TGA-FTIR study of the thermal and SBA-15-catalytic pyrolysis of potassium citrate under nitrogen and air atmospheres. Journal of Analytical and Applied Pyrolysis, 125: 144-152, 2017.

doi: 10.1016/j.jaap.2017.04.007

[27] Trettenhahn G, Köberl A. Anodic decomposition of citric acid on gold and stainless steel electrodes: An in situ-FTIRspectroscopic investigation. Electrochimica Acta, 52 (7): 27162722, 2007.

doi: $10.1016 /$ j.electacta.2006.09.028

[28] Chinarro E, Jurado J. R, Colomer M. T. Synthesis of ceria-based electrolyte nanometric powders by urea-combustion technique. Instituto de Cerámica y Vidrio, ICV-CSIC, C/Kelsen No 5, 28049 Madrid, Spain Available online 2 April 2007.

doi: 10.1016/j.jeurceramsoc.2007.02.007 
[29] Farhikhteh S, Maghsoudipour A, Raissi B. Synthesis of nanocrystalline $\mathrm{YSZ}\left(\mathrm{ZrO}_{2}-8 \mathrm{Y}_{2} \mathrm{O}_{3}\right)$ powder by polymerized complex method. Journal of Alloys and Compounds, 491(1-2): 402405, 2010.

doi: 10.1016/j.jallcom.2009.10.196

[30] Romero M, Pardo H, Faccio R, Suescun L, Vázquez S, Laborda I, Fernández-Werner L, Acosta A, Castiglioni J, Mombrú A. W. A Study on the Polymer Precursor Formation and Microstructure Evolution of Square-Shaped $\left(\mathrm{La}_{0.5} \mathrm{Ba}_{0.5}\right)\left(\mathrm{Mn}_{0.5} \mathrm{Fe}_{0.5}\right) \mathrm{O}_{3}$ Ceramic Nanoparticles. Journal of Ceramic Science and Technology, 06: 221 230, 2015.

doi: 10.4416/JCST2015-00005

[31] Ganapathy S, Adams BD, Stenou G, Anastasaki MS, Goubitz K, Miao XF, Nazar LF, Wagemaker M. Nature of $\mathrm{Li}_{2} \mathrm{O}_{2}$ Oxidation in a $\mathrm{Li}_{2} \mathrm{O}_{2}$ Battery Revealed by Operando X-ray Diffraction. Journal of the American Chemical Society, 136: 16335-16344, 2014.

doi: $10.1021 /$ ja508794r

[32] Gao J, Cai X, Wang J, Hou M, Lai L, Zhang L. Recent progress in hierarchically structured $\mathrm{O}_{2}$-cathodes for $\mathrm{Li}_{-} \mathrm{O}_{2}$ batteries. Chemical Engineering Journal, 352: 972-995, 2018.

doi: 10.1016/j.cej.2018.06.014

[33] Cabrera S, Benavente F, Vargas M, Flores JL, Ortega M, Villca J, Mamani R, Leiva N, Luna M, Yapu W, Blanco M, Palenque ER, Balanza R. Perspectivas En El Procesamiento De Materiales - Electrodos Para Baterías De Ion Litio En Bolivia. Revista Boliviana de Quimica, 29:1, 2012.

http:// www.scielo.org.bo/ scielo.php? script=sci_ arttext\&pid=S0250-54602012000100003

[34] Levi M, Gamolsky K, Aurbach D, Heider U, Oesten R. On electrochemical impedance measurements of $\mathrm{Li}_{\mathrm{X}} \mathrm{Co}_{0.2} \mathrm{Ni}_{0.8} \mathrm{O}_{2}$ and $\mathrm{Li}_{\mathrm{X}} \mathrm{NiO}_{2}$ intercalation electrodes. Electrochemical Acta, 45: 1781-1789, 2000.

doi: 10.1016/S0013-4686(99)00402-8

[35] Kalyani P, Kalaiselvi N. Various Aspects of $\mathrm{LiNiO}_{2}$ chemistry: A review. Science and technology of advanced materials, 6: 689, 2005.

doi: 10.1016/j.stam.2005.06.001 
[36] Burba C, Shaju K, Bruce P, Frech R. Infrared and Raman spectroscopy of nanostructured $\mathrm{LT}-\mathrm{LiCoO}_{2}$ cathodes for Li-ion rechargeable batteries. Vibrational Spectroscopy, 51: 248-250, 2009. doi: 10.1016/j.vibspec.2009.06.002

[37] Kempaiah R, Vasudevamurthy G, Subramanian A. Scanning probe microscopy based characterization of battery materials, interfaces, and processes. Nano Energy, 65: 103925, 2019.

doi: 10.1016/j.nanoen.2019.103925

[38] Matsuda Y, Kuwata N, Okawa T, Dorai A, Kawamura J. In situ Raman spectroscopy of $\mathrm{Li}_{\mathrm{X}} \mathrm{CoO}_{2}$ cathode in $\mathrm{Li} / \mathrm{Li}_{3} \mathrm{PO}_{4} /$ $\mathrm{LiCoO}_{2}$ all-solid-state thin-film lithium battery. Solid State Ionics, 335: 7-14, 2019.

doi: 10.1016/j.ssi.2019.02.010

[39] Otoyama M, Ito Y, Hayashi A, Tatsumisago M. Raman imaging for $\mathrm{LiCoO}_{2}$ composite positive electrodes in all-solidstate lithium batteries using $\mathrm{Li}_{2} \mathrm{~S}-\mathrm{P}_{2} \mathrm{~S}_{5}$ solid electrolytes. Journal of Power Sources, 302: 419-425, 2016.

doi: 10.1016/j.jpowsour.2015.10.040

[40] Porthault H, Baddour-Hadjean R, Le Cras F, Bourbon C, Franger S. Raman study of the spinel-to-layered phase transformation in sol-gel $\mathrm{LiCoO}_{2}$ cathode powders as a function of the post-annealing temperature. Vibrational Spectroscopy, 62: 152-158, 2012.

doi: 10.1016/j.vibspec.2012.05.004

[41] Lin J, Zeng C, Wang L, Pan Y, Su C. Y. Self-standing MOFderived $\mathrm{LiCoO}_{2}$ nanopolyhedron on Au-coated copper foam as advanced 3D cathodes for lithium-ion batteries. Applied Materials Today, 19: 100565, 2020.

doi: 10.1016/j.apmt.2020.100565

[42] Julien C, Letranchant C, Rangan S, Lemal M, Ziolkiewics S, Castro-García S, El Fahr L, Benkaddour M. Layered $\mathrm{LiNi}_{0.5} \mathrm{Co}_{0.5} \mathrm{O}_{2}$ cathode materials grown by soft-chemistry via various solution methods. Materials Science and Engineering, 76: 145. 2000.

doi: 10.1016/s0921-5107(00)00431-1

[43] Escobar L, Haro E. Structure and electrochemistry of thinfilm oxides grown by laser-pulsed deposition. Materials Chemistry and Physics, 68: 210-216, 2001.

doi: 10.1007/BF02419223 
[44] Okubo M, Hosono E, Kim J, Enomoto M. Nanosize effect on high-rate Li-ion intercalation in $\mathrm{LiCoO}_{2}$ electrode. Journal of the American Chemical Society, 129: 7444-7452, 2007.

doi: 10.1021/ja0681927

[45] Freitas B, Siqueira J, da Costa L, Ferreira G, Resende J. Synthesis and Characterization of $\mathrm{LiCoO}_{2}$ from Different Precursors by Sol Gel Method. Journal of the Brazilian Chemical Society, 28(11): 2254-2266, 2017.

doi: 10.21577/0103-5053.20170077

[46] Myung S, Khalil A, Yang-Kook S. Nanostructured cathode materials for rechargeable lithium batteries. Journal of Power Sources, 283: 219-236, 2015.

doi: 10.1016/j.jpowsour.2015.02.119

[47] Guo Z, Konstantinov P, Wang G, Liu H, Dou S. Preparation of orthorhornbic $\mathrm{LiMnO}_{2}$ material via the sol-gel process. Journal of Power Sources, 119: 221 225, 2003.

doi: 10.1016/S0378-7753(03)00237-4

[48] Ellmer K. Transparent conductive Zinc oxide, Springer Series in materials science, Ed. Springer Berlin Heidelberg, 2008.

[49] Zuo D, Tian G, Li X, Chen D, Shu K. Recent progress in surface coating of cathode materials for lithium ion secondary batteries. Journal of Alloys and Compounds, 706: 24-40, 2017.

doi: 10.1016/j.jallcom.2017.02.230

[50] Yina H, Brodardb P, Sugnauxa C, Fromm KM, Kwona NH. Impact of composite structure and morphology on electronic and ionic conductivity of carbon contained $\mathrm{LiCoO}_{2}$ cathode. Electrochimica Acta, 134: 215-221, 2014.

http://doc.rero.ch/record/211399/files/fro_ics.pdf

[51] Choi WG, Yoon SG. Structural and electrical properties of $\mathrm{LiCoO}_{2}$ thin-film cathodes deposited on planar and trench structures by liquid-delivery metal-organic chemical vapour deposition. Journal of Power Sources, 125 (2): 236-241, 2004.

doi: 10.1016/j.jpowsour.2003.08.014 
[52] Park MS, Hyun SH, Nam SC. Mechanical and electrical properties of a $\mathrm{LiCoO}_{2}$ cathode prepared by screen-printing for a lithiumion micro-battery. Electrochimica Acta, 52(28): 7895-7902, 2007.

doi: 10.1016/j.electacta.2007.06.041

[53] Xue J, Jiang C, Pan B, Zou Z. Constructing multidimensional conducting networks on $\mathrm{LiCoO}_{2}$ cathode for enhanced rate performance and cycle stability. Journal of Electroanalytical Chemistry, 850, 2019.

doi: 10.1016/j.jelechem.2019.113419

\section{Síntesis química y caracterización del estado estacionario de un óxido de litio cobalto nanocristalino}

Resumen: El óxido de litio cobalto $\left(\mathrm{LiCoO}_{2}\right)$ es uno de los componentes más relevantes en las baterías de ion de litio. El conjunto de características por las que se cotiza el $\mathrm{LiCoO}_{2}$ depende de su método de síntesis. En este trabajo se sintetizó y caracterizó un oxido $\mathrm{LiCoO}_{2}$ nanocristalino, obtenido con un método de síntesis de química húmeda. El óxido obtenido fue un polvo homogéneo en el rango nanométrico $(5-8 \mathrm{~nm})$ y exhibió una serie de propiedades mejoradas. La caracterización por medio de técnicas FTIR y UV-Vis llevó a la identificación de especies de citrato como productos principales en el primer paso del proceso de síntesis. La caracterización por difracción por rayos-X (XRD), Raman y microscopía de transmisión electrónica (TEM) condujo a la identificación de la fase cristalina pura del óxido $\mathrm{LiCoO}_{2}$ sintetizado. La caracterización eléctrica del estado estacionario y la espectroscopía de impedancia del estado sólido determinaron la alta conductancia del óxido sintetizado. Todas estas características son deseables en el diseño de cátodos para las baterías de ion de litio.

Palabras clave: Nanomaterial; Baterías ion-Li; nanocristalino; estado estacionario. 


\section{Síntese química e caracterização do estado estacionário de um óxido de lítio cobalto nanocristalino}

Resumo: $\mathrm{O}$ óxido de lítio cobalto $\left(\mathrm{LiCoO}_{2}\right)$ é um dos componentes mais relevantes nas baterias de íon de lítio. $\mathrm{O}$ conjunto de características pelas quais se cotiza o $\mathrm{LiCoO}_{2}$ depende de seu método de sínteses. Neste trabalho se sintetizamos e caracterizamos um $\mathrm{LiCoO}_{2}$ nanocristalino, obtido com um método de síntese de química úmida. O óxido obtido foi um pó homogéneo em faixa nanométrica $(5-8 \mathrm{~nm})$ e presentou uma série de propriedades melhoradas. A caracterização por meio de técnicas FTIR e UV-Vis levou a identificação de espécies de citrato como produtos principais no primeiro passo do processo de síntese. A caracterização por difração de raios X (XRD), Raman e microscopia de transmissão eletrônica (TEM) levou a uma identificação de uma fase cristalina pura do $\mathrm{LiCoO}_{2}$ sintetizado. A caracterização elétrica do estado estacionário e da espectroscopia de impedância do estado solido determinaram a alta condutância do oxido sintetizado. Todas essas características são desejáveis no desenho de cátodos para as baterias de íon de lítio.

Palavras-chave: Nanomateriais; baterias íon-Li; nanocristalino; estado estacionário. 


\section{Jairo Alberto Gómez Cuaspud}

Chemist and Doctor in Chemical Sciences with extensive experience in the synthesis of advanced solid state materials for different types of applications related with power generation. Full time full professor at the Universidad Pedagógica y Tecnológica de Colombia and Associate Researcher MINCIENCIAS (2020), belonging to the Institute for Research and Innovation in Materials Science and Technology (INCITEMA) and the materials integrity and evaluation group (GIEM).

ORCID: 0000-0002-9645-516X

\section{Ariatna Yizel Neira Guio}

Master in Chemistry from the Universidad Pedagógica y Tecnológica de Colombia, Chemistry graduated from the same university, with experience in research on the analysis and synthesis of advanced materials such as nanomaterials applied to the development of lithium-ion batteries, a topic in which I have some publications of the national order.

ORCID: 0000-0001-5519-4939

\section{Luís Carlos Canaría Camargo}

I have completed undergraduate studies in Mathematical Education Sciences at the Universidad Pedagógica y Tecnológica de Colombia (UPTC), Master in Mathematical Sciences at the National University of Colombia, and currently be a Ph.D student in Engineering and Materials Sciences at UPTC. I have been teaching at UPTC since 2010 where I have enrolled in the Algebra and Analysis research group of the School of Mathematics and Statistics.

ORCID: 0000-0001-5460-238X 


\section{Enrique Vera López}

Physicist, Doctor in Physics with vast experience in the characterization of advanced materials and applications in electrochemistry and corrosion. Full time full professor at the Pedagogical and Technological University of Colombia and Senior Researcher MINCIENCIAS (2020), scientific director of the Institute for Research and Innovation in Materials Science and Technology (INCITEMA) and leader of the materials integrity and evaluation group (GIEM).

ORCID: 0000-0003-4150-9308 